\title{
A Case Study: Are Traditional Face-To-Face Lectures Still Relevant When Teaching Engineering Courses?
}

\author{
http://dx.doi.org/10.3991/ijep.v3iS4.3161 \\ Shahid Alam and LillAnne Jackson \\ University of Victoria, BC, Canada
}

\begin{abstract}
In this rapidly changing age, with virtually all information available on the Internet including courses, students may not find any reason to physically attend the lectures. In spite of the many benefits the online lectures and materials bring to teaching, this drift from the traditional (norm) face-to-face lectures is also creating further barriers, such as difficulty in communicating and building personal relationships, between students and instructor. In this paper we carry out a study that presents and analyzes factors that motivate students to attend a (1) face-to-face instruction inclass versus an (2) online class. This study is based on an anonymous and voluntary survey that was conducted in the School of Engineering at University of Victoria, BC, Canada. This paper presents and shares the detailed results and analysis of this survey that also includes some interesting and useful comments from the students. Based on the results, analysis and comments the paper suggests methodologies of how to improve face-to-face in-class instructions to make them more relevant to the current global information age.
\end{abstract}

Index Terms-Engineering education; global information age; e-learning; students' motivation; face-to-face classes; online classes; case-study

\section{INTRODUCTION}

A decade ago information was available in one form or another but not in a global form. Due to current advancements in technology the same information is available globally, yielding the current global information age.

The abundance of information can make it difficult to filter yielding advantages and disadvantages. A soybean farmer in India can check the latest prices of soybean on the web site [24] of Chicago Board of Trade and hence make an informed and better decision when to sell his/her crops. On the other hand this information can make a person addictive to the Internet. As a consequence can interfere with his/her daily life, work and relationships.

Many of the courses in North American universities are available to public to read, watch or even attend online. For example: Anyone in the world who has access to Internet can attend any of the courses offered by one of the top universities in the world [2, 6, 7, 5, 4, 3].

MIT OpenCourseware [2] publishes online course materials for more than 2000 of the same courses offered at MIT. As of December 2012 they have more than 125 million visitors. Some of the other North American universities that enable faculty, students and others to share their educational and research resources with the global learning community are: University of Michigan [6], Yale University [7], University of California Berkeley [5], Stanford University [4] and Princeton University [3]. Similar other initiatives are found in Europe [11], Australia [8], Canada [23], China [1], India [20] and other countries.

According to the surveys of the Internet use [10], conducted by Statistics Canada in the years 2007, 2009 and 2010, almost 50\% of the people in Canada use Internet for education, training and school work, and almost $90 \%$ of these people have a University degree (higher education).

\section{Students' Motivation}

Rodgers et al. [21] indicates that the student attendance at Australian and US Universities is declining. Various other researches $[13,12,14,18]$ has also indicated that student attendance at face-to-face lectures in higher education institutions is declining. Many Canadian academics have observed the same trend.

Bassili [9] carried out an empirical study and made a case that the choice to attend lectures or watch them online depends on the motivation of the students, and the actual attendance depends on the cognitive strategies of the students. The survey included a set of questions about motivation such as: goals, intrinsic and extrinsic interests and feelings of self efficacy, and cognitive strategies such as: attention, critical thinking, monitoring and organization of information in memory. Based on the results of the survey the study concluded:

1. Students who valued the course highly and were extrinsically motivated to learn its contents had a more positive attitude towards online lectures.

2. Students who like learning with peers and tend to use cognitive strategies that involve monitoring tended to attend lectures rather than watch them online.

To improve lecture attendance we ask ourself two questions based on the study carried out by Bassili [9]:

Should we train the students and develop their cognitive strategies so more students attend lectures? Or should we change and improve the lectures so students are motivated to attend them?

These two questions motivated us to conduct the study. The rest of the paper is organized as follows: Section III provides a literature review. Section IV describes the 
survey in detail including the questionnaire used, the data analysis and the results. Section $\mathrm{V}$ analyzes and provides discussion about the results of the survey. Section VI lists some of the recommendations based on the results of the survey. Section VII finally concludes the paper.

\section{LITERATURE REVIEW}

In this Section we review recent literature on student motivation and class attendance that relates to the study carried out in this paper.

The study carried out by Sarah Moore, Claire Armstrong and Jill Pearson [19] provides evidence that a student performance in a course depends on his/her lecture attendance. The study also provides the reasons for absenteeism among students in higher education. A survey was conducted and the students were asked 3 main questions. One of them was to describe the reasons for not attending the lectures.

The results of the survey show that a large percentage of students do not bother to attend lectures and the reasons can be: psychological, emotional and a coping mechanism to deal with other problems. There was no mention about whether lectures available online affected attendance.

Gabrielle Kelly [17] also made a case of relating performance and retention rates at universities with not attending individual courses, and that attendance is related to students' motivation and satisfaction with their course. A survey was conducted of undergraduate students in the School of Mathematics and two of the Science Colleges at University of Dublin, Ireland. The questions include the factors for not attending, such as weather, time table etc and factors that will improve attendance, such as course quality etc.

Based on the results of the survey the authors made following recommendations to improve attendance: Provide on-campus housing and flexible class scheduling, change student fees, improve lecture qualities, and include activity based learning.

The survey was conducted during the midterm exam and the reason given for this in the paper was to include the non-attendees. In our opinion this forced participation can make the students answer some of the questions under pressure and hence can produce wrong answers/results. Other methods could have been used to include nonattendees, such as an online survey where the student does not have to be present in the class and can freely express his/her opinion.

The study carried out by Krystyna Sawon, Michael Pembroke and Patrick Wille [22] was motivated by the fact that attendance is declining in Australian universities and sought to profile attendee and non-attendee students. A survey of undergraduate students in a business degree program was conducted. Students were divided into two groups: one of them claimed attending more than $50 \%$ of the lectures and the other claimed attending less than 50\% of the lectures. These two groups were classified as good and bad attendees. The survey included both background (gender, age, employment and distance traveled etc) and behavioral (goals and attitudes etc) questions.

Both groups answered that the lectures were easy. $12 \%$ of the bad attendees found the lectures boring and were able to obtain the lectures in other ways. The other bad attendees found the lectures interesting but even then attended less than half of the lectures. In our opinion, the bad attendees, who found the lectures interesting, did not attend more than half of the lectures because they did not find intellectual challenge in the lectures.

A study presented by Inglis et al. [16] tried to answer a specific question: How often students attended face-toface lectures, online lectures and a mathematical learning support center during a calculus course. The main motivation for this study was to present the students with all the resources and let them choose what they think to be the most effective means of achieving their learning outcomes.

534 students participated in the study. 237 from mathematics and 297 from engineering. Students who primarily attended online lectures were not very successful academically. Students who attended both faceto-face lectures and the mathematical support center were more successful academically. As the face-to-face lectures and the mathematical support center the online lectures were also provided in a controlled environment.

It is not clear if the students used other online resources. Such as the group who attended the face-to-face lectures and the mathematical support center might have used the other online resources more than the one's who primarily attended the online lectures.

A study by Akers et al. [15] asked students why they attend lectures despite the availability of abundant online materials. This survey was carried out in the School of Molecular Bioscience at University of Sydney. The authors made a case that presence of the web based learning technologies can reduce the attendance of students at lectures and hence can affect their performance in studies.

The reasons given by the students for attending lectures were: Discipline, better learning environment, university experience, social aspect, a habit, guilt and financial concerns. The reasons given by the students for not attending lectures were: Sickness, inconvenience, large class distraction and timetable clash. The reasons given by students for liking the online lectures/materials were: The ability to work at their own pace, time and without peer distractions.

$82 \%$ of the students surveyed in this study reported, though not verified, that they always or mostly attended lectures. It would have been good to verify attendance by some other means as is done in [17].

None of the studies mentioned above asked directly, for general comments and suggestions from, the students about the factors that would influence and improve their attendance at class lectures. The study described in [15] only asked comments to the specific questions. This is the main difference between the study carried out in this paper and the studies mentioned above.

\section{THE SURVEY}

To find student's motivation to attend in-class lectures we carried out a survey in the first quarter of the year 2013. Our target population was all the undergraduate students in the College of Engineering at University of Victoria. The survey was conducted online [25].

The responses to the questionnaire were completely anonymous and entirely confidential. Participation was completely voluntary. 
The following assumptions about the survey were conveyed to the participants: (1) That there are no restrictions (i.e; attendance is not mandatory) on attendance in both face-to-face and online classes. (2) That most of the participants, if have not attended, are familiar with online classes/courses, and know the basics.

Total 245 number of students participated in the survey. Table I shows the distribution of these students according to their department, year in degree, gender and the proportion of the time they spent on Internet and in Class.

\section{A. Questionnaire}

In the survey we asked the students about their department, the year of degree, gender and residency. This survey is about the class attendance and the time on the Internet for education, so we also asked them about the time they spent on the Internet for education, training or school work, and the proportion of class lectures they attend. The answers to these questions are summarized in Table I.

TABLE I.

DisTRIBUTION OF THE SURVEY PARTICIPANTS (STUDENTS)

\begin{tabular}{|l|c|}
\hline \multicolumn{1}{|c|}{ Department } & Number of Students (\%) \\
\hline Computer Science & 29.39 \\
\hline $\begin{array}{l}\text { Electrical and Computer } \\
\text { Engineering }\end{array}$ & 38.78 \\
\hline Mechanical Engineering & 31.84 \\
\hline \multicolumn{1}{|c|}{ Year in Degree } & 14.29 \\
\hline First & 24.08 \\
\hline Second & 27.76 \\
\hline Third & 33.88 \\
\hline Fourth Gender & 15.1 \\
\hline \multicolumn{1}{|c|}{ Proportion of the } & 84.9 \\
\hline Female & \\
\hline Male & \\
\hline 15imt & \\
\hline $25 \%$ or less spent on Internet & 44.9 \\
\hline $25 \%$ or less spent in Class & 15.51 \\
\hline $50 \%$ spent on Internet & 34.69 \\
\hline $50 \%$ spent in Class & 13.88 \\
\hline $75 \%$ or more spent on Internet & 20.41 \\
\hline $75 \%$ or more spent in Class & 76.61 \\
\hline
\end{tabular}

1 Proportion of time a student spent on Internet and in class. e.g from the second last and the last row:

$\mathbf{2 0 . 4 1 \%}$ of the students spent $\mathbf{7 5 \%}$ or more of their time on Internet and $\mathbf{7 6 . 6 1 \%}$ of the students spent $\mathbf{7 5 \%}$ or more of their time in class

The survey consisted of total 12 questions. All these questions can be read online [25]. Question number 7 had 13 close ended (yes/no) sub-questions. Figure 1 presents the distribution of the answers by the survey participants to these 13 questions. We reproduce the complete question 7 as follows:

Q7. When all the supporting materials and lectures for a course are available online, what you think are the most common reasons for attending the lecture in class. Please check all that apply:

Q7-1. Face to face interactions with the instructor and other students
Q7-2. To develop a more personal learning relationship with the instructor

Q7-3. Like the environments (feel realistic and not virtual) Q7-4. Getting the material first hand rather than from other sources

Q7-5. To feel more engaged and productive

Q7-6. Social interactions (such as finding study colleagues) are much easier

Q7-7. More interactive and productive class discussions

Q7-8. Will learn something that is not available online (such as: hands on experience or demonstration, face-toface feedback from the instructor and the students)

Q7-9. Intellectually challenging

Q7-10. Just a habit

Q7-11. Feeling guilty

Q7-12. Financial reasons (e.g: The cost benefit approach if the in class lecture provides more value than other activities)

Q7-13. Smaller class sizes i.e; less than 30

Q7-14. Other please specify:

The other questions included in the survey were about the current and the future attendance improvement and its effect on the student's academic performance. The students were also asked for any general comments and suggestions which would influence and improve their attendance at class lectures. These questions (Q8 - Q12) are reproduced as follows:

Q8. How has your attendance changed since you started at university?

Choices: Improved About the same Declined

Q9. Looking ahead do you expect your attendance to

Choices: Improve Remain about the same Decline

Q10. Do you think that lack of attendance at class lectures affects your academic performance?

Choices: Yes No

Q11. Have you any general comments on attendance that you would like to make:

Q12. Have you any suggestions of things the University could do, or changes the University could make, which would influence your attendance at class lectures:

Some of the questions in the survey were close ended questions as listed above (Q7-1 to Q7-13), especially about the reasons for attending the class even if all the course material is available online. It's easier to answer 
these type of questions and also give the participants a chance to relate them with their own experiences.

In our opinion the best answer is impromptu. These type of questions in an online survey has the capability to make the participant think at the instant and answer impromptu. To make the survey broader we presented a range of questions to the students and also text boxes were provided for detailed comments. More than $70 \%$ of the students who participated in the survey entered interesting and useful comments. We include and discuss some of them in Section V.

\section{A. Results}

Figure 1 shows how many students answered 'yes' to the 13 close ended questions listed above. Most (over $70 \%$ ) of the students are convinced that their reasons for attending the in-class lectures is the availability of the demonstrations, hands on experiences and face-to-face feedback that are not available online.

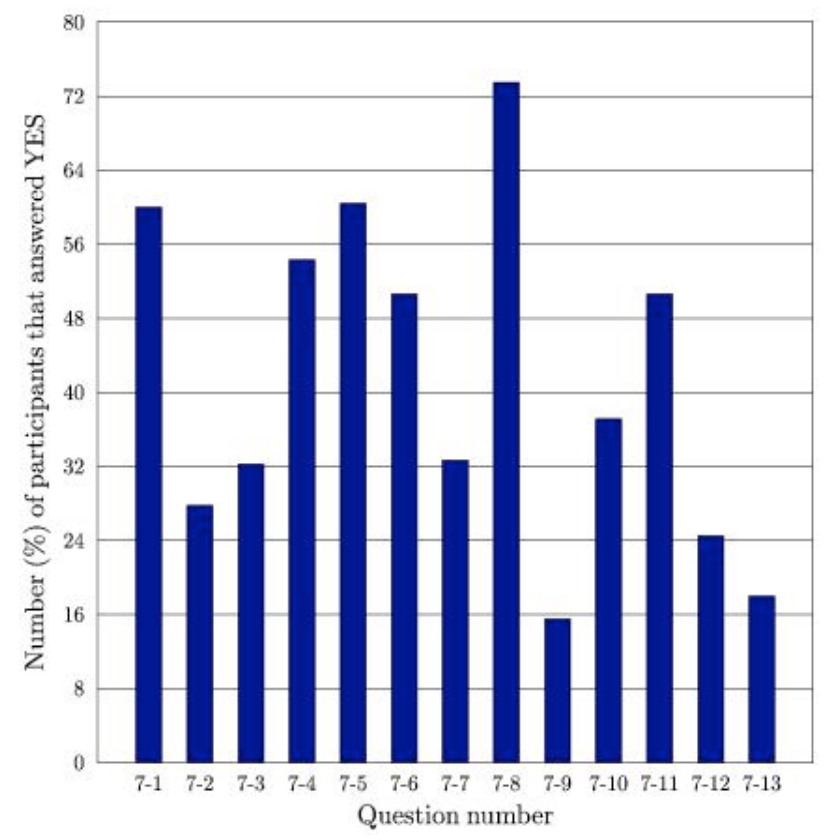

Figure 1. Distribution of the Answers by the Survey Participants (Students) to the 13 Survey Questions Listed in Section IV

Majority of the students (over 50\%) answered 'yes' to questions $1,4,5$ and 6 . These questions are also indirectly related to the factors that are not available online, such as feeling engaged, face-to-face interactions, direct availability of the materials and social interactions. Majority (over 50\%) of the students attend the in-class lectures because of guilty (question 11).

The data in Table I show that $76.61 \%$ of students have good class attendance ( $75 \%$ or more). Table II shows the distribution of class attendance of the students. Most (79.35\% as shown in Table II) of these $76.61 \%$ students belong to the ECE (Electrical and Computer Engineering) department and over 50\% belong to each CS (Computer Science) and ME (Mechanical Engineering) departments.

As the students progress through their degrees their attendance increases as shown in column 3 for Second, Third and Fourth year students. The last row in Table II shows the number of students who spent $50 \%$ or more of their time on the Internet. We can see over $50 \%$ of the students regardless of their class attendance rate spent considerable amount of time on the Internet for education purposes.

When students were asked if in future their attendance is going to improve or remain the same, almost $70 \%$ of them said that it is going to remain the same. $53.47 \%$ of the students said that lack of attendance at class lectures affects their academic performance. We provide analysis and discussion on the results of the survey in the next Section. The next Section also discusses the comments from over $70 \%$ of the students who participated in the survey.

TABLE II.

Distribution of Class AtTENDANCE OF THE SuRvey Participants (STUDENTS)

\begin{tabular}{|c|c|c|c|}
\hline & \multicolumn{3}{|c|}{ Number of Students (\%) } \\
\hline Department & $\begin{array}{c}\text { CA }^{4} 25 \% \\
\text { or Less }\end{array}$ & $\mathrm{CA}^{4} 50 \%$ & $\begin{array}{c}\mathrm{CA}^{4} 75 \% \\
\text { or More }\end{array}$ \\
\hline $\mathrm{CS}^{1}$ & 21.05 & 32.35 & 57.61 \\
\hline $\mathrm{ECE}^{2}$ & 23.68 & 38.24 & 79.35 \\
\hline $\mathrm{ME}^{3}$ & 53.63 & 29.41 & 51.09 \\
\hline \multicolumn{4}{|l|}{$\begin{array}{l}\text { Year in } \\
\text { Degree }\end{array}$} \\
\hline First & 18.42 & 14.71 & 25 \\
\hline Second & 13.16 & 29.41 & 47.83 \\
\hline Third & 31.58 & 23.53 & 51.09 \\
\hline \multirow[t]{4}{*}{ Fourth } & 34.21 & 32.35 & 64.13 \\
\hline & \multicolumn{3}{|c|}{$\begin{array}{c}\text { Number of Students }(\%) \text { Who Spent } \\
50 \% \text { or More of Their Time on the } \\
\text { Internet for Education }\end{array}$} \\
\hline & $\begin{array}{c}\text { CA }^{4} 25 \% \\
\text { or Less }\end{array}$ & $\mathrm{CA}^{4} 50 \%$ & $\begin{array}{c}\mathrm{CA}^{4} 75 \% \\
\text { or More }\end{array}$ \\
\hline & 65.79 & 70.6 & 53.18 \\
\hline
\end{tabular}

$1 \mathrm{CS}=$ Computer Science

2 ECE = Electrical and Computer Engineering

$3 \mathrm{ME}=$ Mechanical Engineering

$4 \mathrm{CA}=$ Class attendance

\section{DisCuSSION AND ANALysis}

The majority (over 50\%) of the students who participated in the survey agreed that the lack of attendance negatively affects their academic performance. This fact is also shown in their good class attendance rate (from Table I: $76.61 \%$ students have a class attendance rate of $75 \%$ or more). Even if the classes do not provide what the student wants (answer 'yes' to the survey questions 7-1, 7-4, 7-5, 7-6 and 7-8 shown in Figure 1: demonstrations, hands on experiences, face-to-face feedback, feeling engaged and social interactions), the majority of the students are going to attend the class lectures. But this attendance may not help improve their academic performance.

Over $70 \%$ of the students provided very interesting comments that we think they deserve a special mention in this paper. Table III classify these comments into 6 different classes of comments, given the number of all the students who provided the same Class of comment and verbatim examples. We only classified those comments that have a sizable number of students with the same Class of comment. 
TABLE III.

ClASSIFICATION OF THE STUDENTS' SURVEY COMMENTS

\begin{tabular}{|c|c|c|}
\hline Class & $\begin{array}{l}\text { Number } \\
\text { of } \\
\text { Students } \\
(\%)\end{array}$ & $\begin{array}{c}\text { Examples from } \\
\text { Students' Comments }\end{array}$ \\
\hline Quality & 56.65 & $\begin{array}{l}\text { - "If the professor adds value to the } \\
\text { course that the material (online) itself } \\
\text { doesn't, students will go". } \\
\text { - "The best classes I've had were the } \\
\text { ones where we sat around and almost } \\
\text { 'argued' about an idea or particular } \\
\text { method". } \\
\text { " "Helpful to hear their (instructors) } \\
\text { train of thought instead of from the } \\
\text { course materials (online)". } \\
\text { - "Ask questions from the class and } \\
\text { engage them in groups to solve a } \\
\text { problem, then instructor can give and } \\
\text { discuss the answer". } \\
\text { " "Instructors simply glide over the } \\
\text { topics and tell us to read the book and } \\
\text { dig deeper to thoroughly know the } \\
\text { concepts. If that's all the instructor is } \\
\text { there to mention, students are more } \\
\text { likely to stay home and study the } \\
\text { material on their own time instead of } \\
\text { wasting time attending lectures that in } \\
\text { essences don't provide any meaningful } \\
\text { knowledge.". } \\
\text { - "In the best courses that I have been } \\
\text { in, the instructor knew nearly all of the } \\
\text { students, regularly got input from the } \\
\text { whole class (not just a few students in } \\
\text { the front), and regularly held some } \\
\text { form of activity like a group discussion } \\
\text { or collectively solving a problem". }\end{array}$ \\
\hline Passion & 23.12 & $\begin{array}{l}\text { - "Instructor cares and personally } \\
\text { engage and connect with students". } \\
\text { - "If the professor is really passionate } \\
\text { about his material and explains } \\
\text { concepts really well and answers } \\
\text { questions, then it's probably worth } \\
\text { going". } \\
\text { - "If the prof only has slides and } \\
\text { strictly sticks to them, I typically stop } \\
\text { attending the lectures because I don't } \\
\text { ind much benefit in attending". } \\
\text { - "There is nothing less appealing than } \\
\text { a professor that drones on in a } \\
\text { monotone voice at the front with zero } \\
\text { excitement or desire to be there. When } \\
\text { they look at teaching as a job, you can } \\
\text { tell, when they look at it as time to } \\
\text { spread their knowledge to the students } \\
\text { and get them excited about the topic it } \\
\text { makes a huge difference". } \\
\text { " "The more passionate an instructor } \\
\text { is on a subject matter, the more } \\
\text { beneficial lecture attendance becomes } \\
\text { as the passion is contagious". }\end{array}$ \\
\hline Time & 13.3 & $\begin{array}{l}\text { - "Early (8:30 am) classes make it } \\
\text { difficult to attend". } \\
\text { - "Of the courses I've had to take at } \\
\text { 8:30 am, I skipped over } 90 \% \text { of the } \\
\text { lectures". }\end{array}$ \\
\hline Online & 12.14 & - "If you can learn in a 5 minute \\
\hline
\end{tabular}

\begin{tabular}{|c|c|c|}
\hline Class & $\begin{array}{l}\text { Number } \\
\text { of } \\
\text { Students } \\
\text { (\%) }\end{array}$ & $\begin{array}{c}\text { Examples from } \\
\text { Students' Comments }\end{array}$ \\
\hline Faster & & $\begin{array}{l}\text { youtube video what a class requires 1- } \\
2 \text { hours to learn, which option would } \\
\text { you take?" } \\
\text { - "Independent learners for the most } \\
\text { part can get away with learning class } \\
\text { material using online resources and } \\
\text { the textbook at a faster more efficient } \\
\text { rate than attending lectures". }\end{array}$ \\
\hline Challenging & 9.83 & $\begin{array}{l}\text { - "Real world problems”. } \\
\text { - "Learning by doing in CS is more } \\
\text { appropriate than listening to lectures } \\
\text { specially for first year courses which } \\
\text { are very simple". } \\
\text { - "If the lectures are boring, why } \\
\text { would I go to class? I don't find myself } \\
\text { very productive coming to class and } \\
\text { have to end up learning on my own } \\
\text { anyways. Why go to calculus, when I } \\
\text { can go on khan academy } \\
\text { (http://www.khanacademy.org) in my } \\
\text { pajamas?". }\end{array}$ \\
\hline $\begin{array}{l}\text { Course } \\
\text { Load }\end{array}$ & 4.62 & $\begin{array}{l}\text { "Attendance often gets sacrificed over } \\
\text { getting assignments or projects done, } \\
\text { which are in my opinion more } \\
\text { interactive than a professor who is } \\
\text { only going over the material". }\end{array}$ \\
\hline
\end{tabular}

One other student's comment that we want to list here is about the virtual class:

"The classroom lecture system provides a learning environment in which learning objectives are presented in a structured and step-by-step manner which feels more real than the virtual environment. 'Virtual' lectures provide good reference material if done correctly, but lack the 'real' feel for a learning experience as does the inclass lectures, and lack the ability for a professor to stop and clarify his or her ideas if students are having trouble understanding. In-class lectures have to feel like a worthwhile use of a student's time."

The student comments have clearly emphasized the quality and passion of teaching. Classes need to contribute, such things that are not available online. The comment (from Table III) which says "we sat around and almost argued about an idea" makes a compelling case for attending classes, as do the train of thought and personal connections comment.

Online learning is faster (Table III, over $12 \%$ comments). If in a class the instructor is only going over the course material (no more usable information than what is available online) a student is not going to attend that class, because the student can learn the same material online much faster. This makes it possible for students to use their time more productively elsewhere.

\section{RECOMMENDATIONS}

Based on the survey results and the comments by the students we recommend some teaching methodologies that can improve attendance in classes.

Quality: To make in class lectures more engaging and accessible to the students bring real life experiences to the class, convey the thoughts and feelings of the instructor. 
The purpose of this method is to move away from a more traditional mechanical style of teaching, and allow students to become an engaged part of the teaching process.

The class room presentation needs to break the norm rather than simply going through course material or slides. For example: In smaller classes the instructor can give feedback to each student on his previous in-class work. In larger classes provide something, such as in-class mini assignments that will definitely motivate a student to attend in-class lectures. As mentioned in a student's comment about engaging in groups to solve a problem.

Imagine an engineering class where the students are the teachers: the class can be divided into groups and, as mentioned in a student's comment, students can sit around and argue about an idea or methodology.

Passion: It is important to be passionate about teaching, both inside and outside of the classroom environment. This makes the instructor more approachable to the students which in turn motivates and engages them inside and outside of the classroom. Let the students feel the passion. Teach better than online.

Challenging: If the class lecture is long then it is easy for a student to get lost in a device, such as a laptop, a tablet computer or a cell phone. Class lectures should always be short and accompanied by in-class activities, as mentioned above.

It is much easier to come up with real-life examples and experiences when teaching an engineering course than with some other course. Almost $10 \%$ (Table III) of the students especially in first and second year courses mentioned relating better to a class with real-life examples.

Course Load: Most of the engineering courses contain assignments and projects. If the course load (assignments and projects) is more than the average, then more class time should be dedicated to these assignments and projects. This can make the course more interesting and challenging for the students and will motivate them to attend the lectures, as mentioned by almost $5 \%$ of the students (Table III).

\section{CONCLUSION}

With all the information available on Internet including course materials and courses, students are finding it difficult to attend in-class lectures. We wanted to find out how to improve classes and motivate students to attend them. We carried out a case study in the form of a survey.

This paper has shared in detail the results of this survey and some of the interesting and useful comments by the participants (students). We have also made a case for making face-to-face lectures more relevant to the current global information age. Based on the results and students' comments we recommended to improve quality and passion in teaching, increase challenge in the lectures and use course load to motivate students to attend in-class lectures.

\section{REFERENCES}

[1] China Open Educational Resources. Available online: http://www.core.org.cn, Last accessed: April 29, 2013.

[2] Massachussets Institute of Technology Open Educational Resources. Available online: http://ocw.mit.edu, Last accessed: April 29, 2013.
[3] Princeton University Open Educational Resources. Available online: http://www.virtualprofessors.com, Last accessed: April 29, 2013.

[4] Stanford University Open Educational Resources. Available online: http://class2go.stanford.edu,Last accessed: April 29, 2013.

[5] University of California Berkeley Open Educational Resources. Available online: http://webcast.berkeley.edu, Last accessed: April 29, 2013.

[6] University of Michigan Open Educational Resources. Available online: http://open.umich.edu, Last accessed: April 29, 2013.

[7] Yale University Open Educational Resources. Available online: http://oyc.yale.edu, Last accessed: April 29, 2013.

[8] Open Universities Australia. Australia Open Educational Resources. Available online: http://www.open.edu.au, Last accessed: April 29, 2013.

[9] John N. Bassili. Motivation and Cognitive Strategies in the Choice to Attend Lectures or Watch them Online. Journal of Distance Education, 22(3):129-148, 2008.

[10] Statistics Canada. Canadian Internet Use Survey (CIUS). Statistics Canada, 2011.

[11] Open Courseware Consortium. Europe Open Educational Resources. Available online: http://opencourseware.eu, Last accessed: April 29, 2013.

[12] L. Corbin, K. Burns, and A. Chrzanowski. If You Teach It, Will They Come-Law Students, Class Attendance and Student Engagement. Legal Educ. Rev., 20:13, 2010.

[13] Australian Council for Educational Research. Doing More for Learning: Enhancing Engagement and Outcomes: Australasian Survey of Student Engagement. ACER, 2010.

[14] S.E. Gump. Guess Whos (not) Coming to Class: Student Attitudes as Indicators of Attendance. Educational Studies, 32(1):39-46, 2006. http://dx.doi.org/10.1080/03055690500415936

[15] Vanessa Gysbers, Jill Johnston, Dale Hancock, and Gareth Denyer. Why do Students still Bother Coming to Lectures, When Everything is Available Online? International Journal of Innovation in Science and Mathematics Education, 19(2):20-36, 2011.

[16] M. Inglis, A. Palipana, Trenholm S., and J. Ward. Individual Differences in Student's use of Optional Learning Resources. Journal of Computer Assisted Learning, 27(6):490-502, 2011. http://dx.doi.org/10.1111/j.1365-2729.2011.00417.x

[17] Gabrielle E. Kelly. Lecture Attendance Rates at University and Related Factors. Journal of Further and Higher Education, 36(1):17-40, 2011.

[18] S. Moore, C. Armstrong, and J. Pearson. Lecture Absenteeism Among Students in Higher Education: A Valuable Route to Understanding Student Motivation. Journal of Higher Education Policy and Management, 30(1):15-24, 2008. http://dx.doi.org/10.1080/13600800701457848

[19] Sarah Moore, Claire Armstrong, and Jill Pearson. Lecture Absenteeism Among Students in Higher Education: a Valuable Route to Understanding Student Motivation. Journal of Higher Education Policy and Management, 30(1):15-24, 2008. http://dx.doi.org/10.1080/13600800701457848

[20] National Program on Technology Enhanced Learning. India Open Educational Resources. Available online: http://nptel.iitm.ac.in, Last accessed: April 29, 2013.

[21] J.R. Rodgers and J.L. Rodgers. Investigation into the Academic Effectiveness of Class Attendance in an Intermediate Microeconomic Theory Class. Faculty of Commerce, University of Wollongong, 2003.

[22] Krystyna Sawon, Michael Pembroke, and Patrick Wille. An Analysis of Student Characteristics and Behaviour in Relation to Absence from Lectures. Journal of Higher Education Policy and Management, 34(6): 575-586, 2012. http://dx.doi.org/10.1080/ 1360080X.2012.716004

[23] Capilano University. Canada Open Educational Resources. available online: http://freelearning.ca, Last accessed: April 29, 2013.

[24] Amy Waldman. India's Soybean Farmers Join the Global Village. The New York Times, January 2004. 
[25] Shahid Alam. A Survey: Student's motivation to attend in-class lectures, @ http://www.cs.uvic.ca/ salam/PhD/TAC/survey.html, copyright (C) University of Victoria, March 17, 2013.

\section{AUTHORS}

S. Alam is a PhD student in the department of Computer Science at University of Victoria, BC V8P 5C2 Canada. He obtained his Masters degree in electrical engineering from Carleton University, Ottawa, ON Canada. (e-mail: salam@cs.uvic.ca).
L. Jackson is an assistant teaching professor in the department of Computer Science and associate dean of undergraduate studies in the college of engineering, at University of Victoria, BC V8P 5C2 Canada. She obtained her $\mathrm{PhD}$ degree in Computer Science from University of Calgary, AB Canada. (e-mail: lillanne@uvic.ca).

This article is an extended and modified version of a paper presented at the 2013 IEEE International Conference on Teaching, Assessment and Learning for Engineering (TALE2013), held 26-29 August 2013, Bali Dynasty Resort, Kuta, Indonesia. Submitted 04 September 2013. Published as re-submitted by the authors 01 December 2013. 